\title{
PROSEDUR PELUNASAN KREDIT DAN PENGAMBILAN DOKUMEN AGUNAN DI BANK TABUNGAN NEGARA CABANG PADANG
}

\author{
Sony Richardo Defrizon, Elva Dona \\ Akademi Keuangan Dan Perbankan "Pembangunan" Padang \\ Sonyrichardo2@gmail.com
}

\begin{abstract}
PT. Bank Tabungan Negara Tbk is one of the companies that provide several products, one of which is Home Ownership Credit or more known as Mortgage Loan. To make it easier for customers to get Mortgage Loans a PT.Bank Tabungan Negara. In the process of collecting and collecting collateral documents at PT. Bank Tabungan Negara Branch of Padang does not complicate the customer in performing Repayment and Collateral Document Taking, even the customer only takes the time specified by the Bank in its repayment takes only 1 day and collateral document collecting that is 3 days can bring Document Collateral. Problem formulation in this research is how procedure of credit repayment and collateral document collecting at PT. Bank Tabungan Negara, and research conducted with purpose to know procedure of credit repayment and collateral document collecting at PT. Bank Tabungan Negara of Padang Branch. The method used in this research is qualitative method. PT. Bank Tabungan Negara is not a company engaged in home sales, but BTN Bank provides convenience to the public, especially padang city in housing finance, the authors also can understand the procedure of credit repayment and document retrieval procedures are very well detailed.
\end{abstract}

Keyword : Procedure, Credit BTN, Home Ownership Credit

\section{PENDAHULUAN}

Perbankan merupakan salah satu institusi yang sangat berperan penting dalam perekonomian suatu negara khususnya dibidang pembiayaan, perekonomian dan pembangunan. Perbankan adalah segala sesuatu yang menyangkut tentang bank, kelembagaan, kegiatan usaha, serta cara dan proses dalam melaksanakan kegiatan usahanya. (Imamah, 2012) Bank adalah suatu badan usaha yang berfungsi menghimpun dana dari masyarakat dalam bentuk simpanan dan menyalurkannya kepada masyarakat dalam bentuk kredit dan atau bentuk-bentuk lainnya dalam rangka meningkatkan taraf hidup rakyat banyak.

Jenis bank berdasarkan kepemilikannya yaitu Badan Usaha Milik Negara (BUMN), Swasta Nasional, Koperasi, Campuran, dan Bank Milik Asing. Bank (BUMN) adalah bank dimana baik akta pendirian maupun modalnya dimiliki oleh pemerintah sehingga seluruh keuntungan bank dimiliki oleh pemerintah pula. Adapun salah satu jenis bank BUMN adalah Bank Tabungan Negara (BTN). 
Bank Tabungan Negara adalah Badan Usaha Milik Negara Indonesia yang berbentuk Perseroan Terbatas (PT) dan bergerak dibidang jasa keuangan perbankan. PT. Bank Tabungan Negara merupakan salah satu dari perusahaan yang menyediakan beberapa produk salah satunya yaitu Kredit Pemilikan Rumah (KPR) dimana kredit ini mempermudah nasabah mendapat rumah yang di inginkan pada wilayah kota dan kecamatan. BTN cabang Padang melayani kredit perumahan bagi masyarakat Kota Padang dan sekitarnya. Perkembangan permintaan kredit pada bank BTN cabang Padang selalu mengalami peningkatan seiring dengan itu jumlah pelunasan kredit pada tahun 2016 sejumlah 3.725 nasabah pada jangka waktu kredit pelunasan yang berkisar 5 sampai 15 tahun, dan pada tahun 2017 sejumlah 3.779 nasabah. Pelunasan ini mengalami peningkatan tipis sejumlah $0,01 \%$.

Nasabah yang sudah jatuh tempo pelunasan kredit dan pengambilan dokumen agunan, dapat langsung melakukan pelunasan kredit dan pengambilan dokumen agunan ke bank BTN cabang Padang. Dalam proses pelunasanya nasabah hanya melakukan sesuai prosedur dan syarat-syarat, dimana membutuhkan waktu 4 hari sampai ke pengambilan dokumen agunan.

Dalam pengambilan dokumen nasabah harus memperhatikan jangka waktu maksudnya disini karena dokumen nasabah itu surat berharga jadi bank tidak mau mengambil resiko kalau terjadi sesuatu dengan dokumen tersebut, untuk itu nasabah bank BTN harus mengambil dokumen dalam waktu yang ditentukan, karena nasabah bisa dikenakan denda bila tidak mengambil dokumen sesuai dengan waktu yang telah ditentukan.

Prosedur pelunasan kredit dan pengambilan dokumen agunan di PT. BTN cabang Padang harus diketahui nasabah dan calon nasabah sebelum melakukan transaksi kredit perumahan, sehingga nasabah dan calon nasabah tersebut mendapat gambaran pada awalnya, untuk itu penulis merasa perlu untuk memaparkan langkah-langkah atau prosedur pelunasan kredit dan proses pengambilan agunan yang ada di PT. Bank Tabungan Negara dalam hal ini mengambil pada cabang Padang.

Berdasarkan uraian diatas penulis mengambil judul untuk tugas akhir ini dengan "Prosedur Pelunasan Kredit dan Pengambilan Dokumen Agunan Di Bank Tabungan Negara Cabang Padang “.

\section{Perumusan Masalah}

Berdasarkan latar belakang yang telah diuraikan di atas, maka rumusan masalah dalam penelitian ini adalah bagaimana prosedur pelunasan kredit dan pengambilan dokumen agunan pada PT. Bank Tabungan Negara Cabang Padang?

\section{Tujuan Penelitian}

Berdasarkan dari perumusan masalah diatas, penelitian dilakukan dengan tujuan untuk mengetahui prosedur pelunasan kredit dan pengambilan dokumen agunan pada PT. Bank Tabungan Negara Cabang Padang?

\section{Manfaat Penelitian}

Penelitian ini diharapkan dapat memberikan manfaat kepada beberapa pihak, diantaranya: 
a. Bagi penulis

dapat meningkatkan pengetahuan dan wawasan dalam bidang pengkreditan perumahan, penjualan yang sesuai dangan teori yang diperoleh dalam perkuliahan.

b. Bagi perusahaan

diharapkan dapartemen berikan gambaran mengenai pengolahan data kredit khususnya dalam pelunasan kredit KPR di Bank BTN.

c. Bagi peneliti lebih lanjut

menambah wawasan mahasiswa yang di dapat selama latihan kerja mengenai pengolahan data kredit khususnya kredit KPR di bank BTN.

\section{Metode Penelitian}

\section{Metode Pengumpulan Data}

Dalam penelitian ini penulis menggunakan metode pengumpulan data dengan, Observasi. Yaitu dengan melakukan wawancara pada bagian kredit (Loan Admin) Pada PT. Bank Tabungan Negara Tbk Cabang Padang.

\section{METODE ANALISA DATA}

Adapun metode analisis data yang digunakan adalah metode kualitatif dimana metode ini mendeskripsikan hasil penelitian yang dilakukan pada PT. Bank Tabungan Negara Cabang Padang.

\section{Prosedur Pelunasan Kredit Dan Pengambilan Dokumen Prosedur Pelunasan Kredit}

Dalam melakukan pelunasan kredit nasabah harus mengetahui apa saja syarat dan ketentuan dalam pelunasan kredit (KPR). Syarat dan ketentuan yang harus dibawa yaitu dokumen, dokumen tersebut berisi (Ktp, Buku Tabungan, Kartu Debitur Dan Materai), selanjutnya dokumen-dokumen ini dibawa ke Loan Admin, loan Admin akan meminta nasabah untuk mengisi formulir permohonan pelunasan dan pengambilan dokumen.

Setelah nasabah melakukan pengisian formulir permohonan pelunasan dan pengambilan dokumen, Loan Admin akan mengarahkan nasabah untuk menemui Customer Service. Customer Service akan melakukan pengecekan berapa besarnya biaya yang harus nasabah lunasi. Customer service membuat surat pelunasan rumah nasabah dan nasabah diminta untuk menandatanganinya. Bawa semua document yang diberikan oleh Customer Service, lalu tunggu nomer anda dipanggil kembali oleh Teller untuk memasukan data pelunasan dan pembayaran. Nasabah akan menerima surat rincian pelunasan yang distample lunas dan pemindahan buku dari Teller. Foto copy semua document yang diberikan Teller, dan temui Loan Admin, di sini Loan Admin akan memeriksa berkas terlebih dahulu. Bila document anda benar maka anda akan diminta untk menunggu 3 hari untuk pengambilan document asli. 
Prosedur diatas dapat digambarkan seperti berikut :

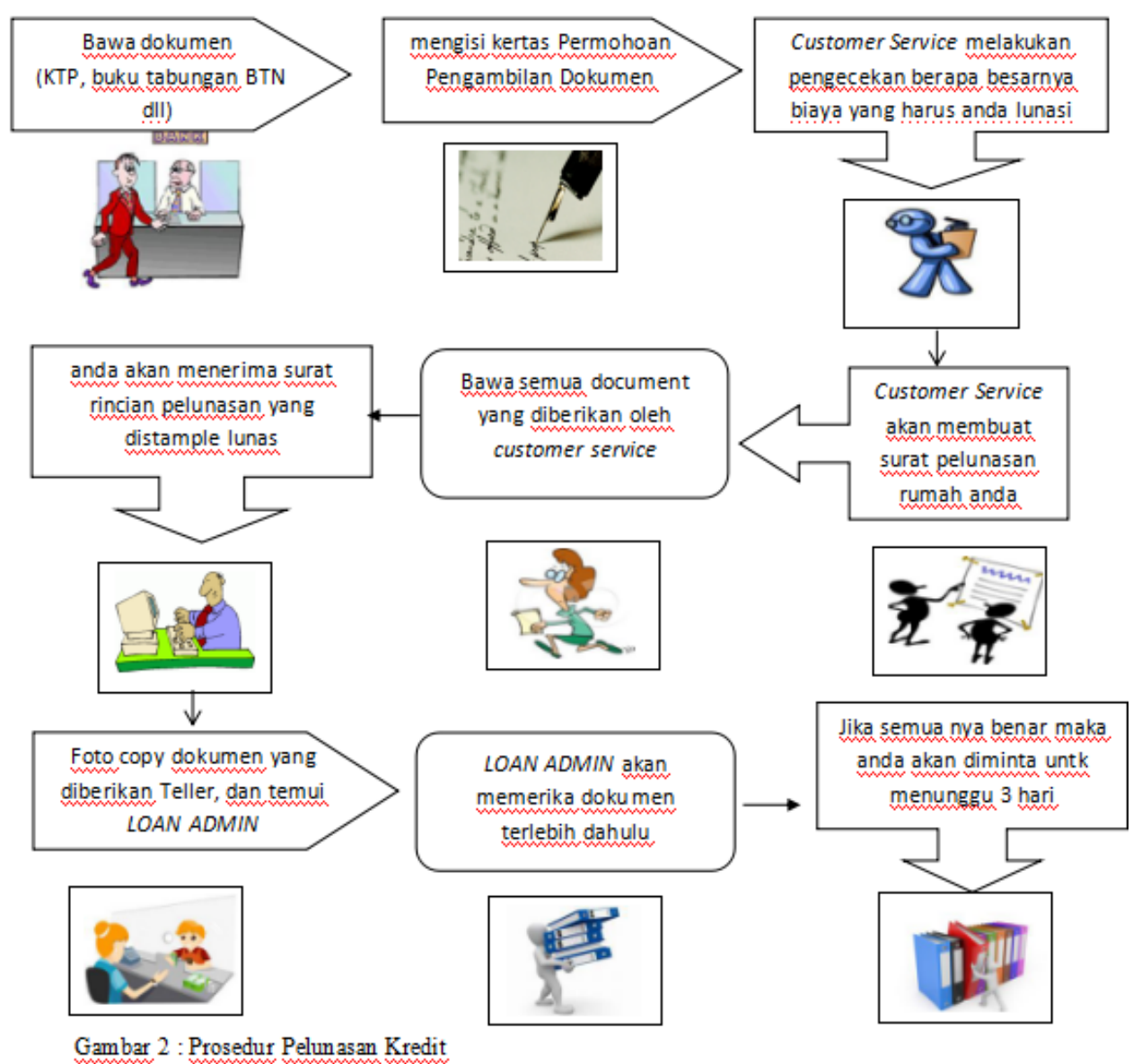

\section{Proses Pengambilan Dokumen PT. Bank Tabungan Negara}

Dalam pengambilan dokumen nasabah harus memperhatikan jangka waktu yang telah diberikan oleh pihak bank, untuk itu nasabah bank BTN harus mengambil dokumen dalam waktu yang ditentukan, karena nasabah bisa dikenakan denda bila tidak mengambil dokumen sesuai dengan waktu yang telah ditentukan, brikut proses pengambilan dokumen:

1. Ambil nomer antrian pengambilan dokumen.

Bawa dokumen:

a. Permohonan pengambilan dokumen (asli) + fotocopy 1

b. Berkas Pelunasan (asli) + fotocopy 1

c. $\mathrm{KTP}$ (asli) + fotocopy 1

d. Kartu Keluarga (asli) + fotocopy 1

e. Buku Nikah (asli) /bila sidah menikah + fotocopy 1

f. Metrai 6000 ( 3 Buah )

2. Tunggu nomer antrian anda dipanggil untuk diperiksa berkas-berkas yang dibawa

3. Setelah diperiksa tunggu lagi nama anda dipanggil. Barulah documentnya keluar

4. Periksa kembali documet yang anda terima.

Berikut ilustrasi alur pengambilan dokumen : 


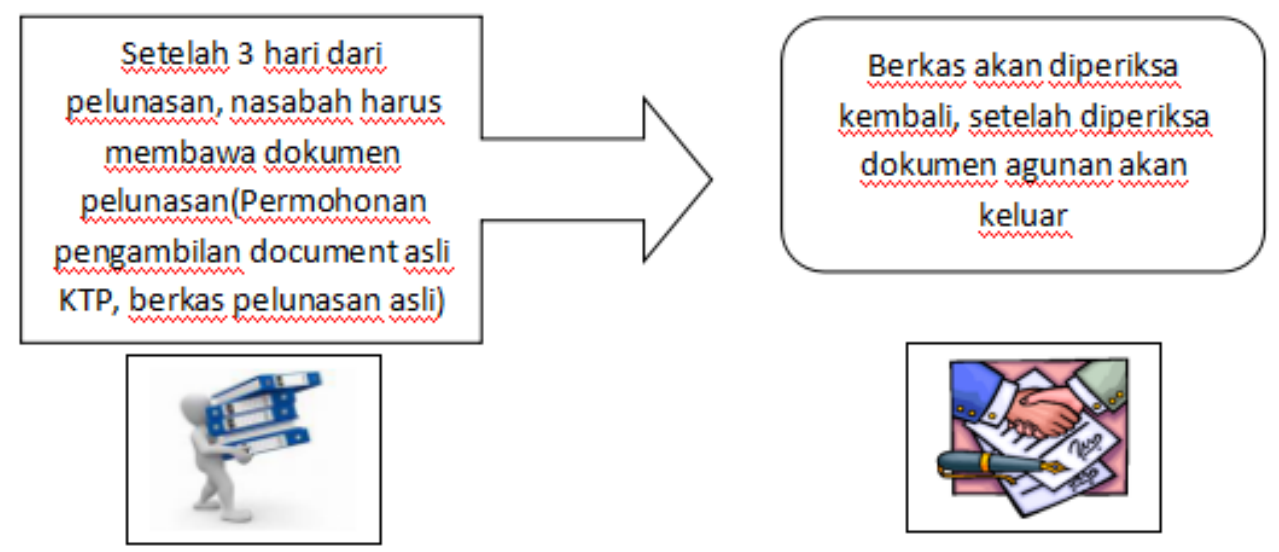

Gambar 3 : Proses Pengambilan Dokumen

Tabel 1

Jumlah Nasabah Yang Melakukan Pelunasan Dan Pengambilan Dokumen

\begin{tabular}{|c|c|c|c|c|}
\hline Bulan & $\begin{array}{c}\text { Jumlah nasabah } \\
\mathbf{2 0 1 6} \text { (Orang) }\end{array}$ & $\begin{array}{c}\text { Perkembangan } \\
\text { (\%) }\end{array}$ & $\begin{array}{c}\text { Jumlah nasabah } \\
\mathbf{2 0 1 7} \text { (Orang) }\end{array}$ & $\begin{array}{c}\text { Perkembangan } \\
\text { (\%) }\end{array}$ \\
\hline Januari & 332 & -0.10 & 315 & 0,04 \\
\hline Febuari & 290 & 0,03 & 330 & -0.06 \\
\hline Maret & 300 & 0,05 & 310 & 0,04 \\
\hline April & 317 & $-0,02$ & 325 & -0.08 \\
\hline Mei & 309 & $-0,03$ & 298 & 0.06 \\
\hline Juni & 298 & 0,07 & 317 & $-0,04$ \\
\hline Juli & 320 & $-0,06$ & 302 & 0,05 \\
\hline Agustus & 300 & 0,04 & 319 & 0,01 \\
\hline September & 312 & $-0,02$ & 325 & $-0,02$ \\
\hline Oktober & 305 & 0,04 & 316 & $-0,04$ \\
\hline November & 320 & 0,06 & 302 & 0,05 \\
\hline Desember & 322 & 0.00 & 320 & 0,00 \\
\hline
\end{tabular}

Sumber : bank BTN

Pada tabel diatas dapat dijelaskan perbandingan Pelunasan dan Pengambilan Dokumen PT.Bank Tabungan Negara pada tahun 2016 dan 2017 terjadinya peningkatan sebesar 0,01\% dalam melakukan pelunasan dan pengambilan dokumen. Pada tahun 2016 dan tahun 2017 jumlah nasabah keseluruhan sebanyak 7.504 Nasabah. Berdasarkan jumlah nasabah yang melakukan pelunasan dan pengambilan dokumen dari PT. Bank Tabungan Negara tahun 2016 dengan jumlah nasabah secara keseluruhan 3.725 nasabah.

Jumlah nasabah yang melakukan pelunasan dan pengambilan dokumen dari PT. Bank Tabungan Negara tahun 2017 dengan jumlah nasabah secara keseluruhan 3.779 nasabah.

Dalam proses pelunasan dan pengambilan dokumen agunan pada PT. Bank Tabungan Negara Cabang Padang tidak mempersulit nasabah dalam melakukan Perlunasan dan Pengambilan Dokumen Agunan, bahkan nasabah hanya membutuhkan waktu yang telah ditentukan oleh pihak Bank dalam melakukan pelunasan nya hanya membutuhkan waktu 1 hari dan pengambilan dokumen agunan yaitu 3 hari sudah bisa membawa Dokumen Agunan. 
apabila nasabah tersebut telah melakukan pelunasan sebagai persyaratan yang diberikan oleh PT. Bank Tabungan Negara, maka dari itu dengan melihat persyaratan yang mudah, proses yang cepat membuat minat para nasabah meningkat dan itu terbukti dari peningkatan jumlah nasabah serta total Pelunasan dan Pengambilan Dokumen Agunan yang diberikan oleh PT. Bank Tabungan Negara yang meningkat dari tahun 2016 ketahun 2017.

Dalam pengambilan dokumen nasabah harus memperhatikan jangka waktu maksudnya disini karena dokumen nasabah itu surat berharga jadi bank tidak mau mengambil resiko kalau terjadi sesuatu dengan dokumen tersebut, untuk itu nasabah bank BTN harus mengambil dokumen dalam waktu yang ditentukan, karena nasabah bisa dikenakan denda bila tidak mengambil dokumen sesuai dengan waktu yang telah ditentukan. Denda yang akan diterima oleh nasabah apabila pengambilan dokumen melebihi jangka waktu yang telah ditentukan oleh pihak Bank tergantung dari jenis dokumenya sendiri, apabila dokumen tersebut berisi Roya, IMB, Sertifikat akan dikenakan denda sebesar Rp. 250.000 (Dua Ratus Lima Puluh Ribu Rupiah) per unit selama telat pengambilan 1 Bulan dan apabila dokumen tersebut berisi Sertifikat akan dikenakan denda sebesar Rp.500.000 (Lima Ratus Ribu Rupiah) selama telat pengambilan 1 Bulan.

Tahun 2017 banyak penurunan jumlah nasabah yang melakukan pelunasan dan pengambilan dokumen. Hal ini terjadi karena kemungkinan adanya nasabah yang waktu nya belum jatuh tempo atau mengalami masalah dengan kredit nya. Dimana Kredit yaitu suatu fasilitas keuangan yang memungkinkan seseorang atau badan usaha untuk meminjam uang untuk membeli produk dan membayarnya kembali dalam jangka waktu yang ditentukan.

UU No. 10 tahun 1998 menyebutkan bahwa kredit adalah penyediaan uang atau tagihan yang dapat dipersamakan dengan itu, berdasarkan persetujuan atau kesepakatan pinjam-meminjam antara bank dengan pihak lain yang mewajibkan pihak meminjam untuk melunasi utangnya setelah jangka waktu tertentu dengan pemberian bunga. Jika seseorang menggunakan jasa kredit, maka ia akan kenakan bunga tagihan (Permana, Tinggi, \& Ekonomi, 2016).

\section{SIMPULAN}

PT. Bank Tabungan Negara Tbk merupakan salah satu perusahaan yang menyediakan beberapa produk salah satunya yaitu Kredit Pemilikan Rumah atau yang lebih di kenal dangan sebutan Kredit KPR. Untuk memudahkan nasabah mendapatkan Kredit KPR. PT. Bank Tabungan Negara

Proses pelunasan kredit dan pengambilan dokumen pada PT bank BTN tidak terlalu rumit dan prosedurnya dapat dipahami dengan baik oleh nasabah, waktu yang diperlukan dalam pelunasan kredit serta pengambilan dokumen dibutuh waktu 4 hari dimana waktu ini tergolong cepat.

PT. Bank Tabungan Negara bukanlah perusahaan yang bergerak dalam bidang penjualan rumah, tapi Bank BTN memberikan kemudahan kepada masyarakat khususnya kota padang dalam pembiayaan perumahan, 
penulis juga dapat memahami prosedur pelunasan kredit dan prosedur pengambilan dokumen sangat terinci dengan baik.

\section{UCAPAN TERIMAKSIH}

Terimakasih penulis sampaikan kepada :

1. Kedua Orang Tua yang senantiasa memberikan dukungan baik secara moril maupun materil.

2. Direktur AKBP beserta prodi AKBP yang telah memberikan kesempatan kepada penulis untuk melakukan penelitian ini.

3. Dosen Pembimbing yang telah memberikan arahan dan bimbingan hingga tugas akhir ini bisa terelesaikan.

4. Pimpinan Cabang PT. Bank Tabungan Negara Cabang Padang yang telah mengizinkan penulis dalam memperoleh informasi beserta pengambilan data.

5. Semua Pihak yang telah memberikan dukungan dan bantuannya dalam penyelesaian tugas akhir ini

\section{DAFTAR PUSTAKA}

Arsip PT. Bank Tabungan Negara (persero), Tbk. Kantor Cabang Padang.

Amelia, L., \& Marlius, D. (2018). Pengendalian Kredit Dalam Upaya Menciptakan Bank Yang Sehat Pada PT. Bank Pembangunan Daerah Sumatera Barat Cabang Utama Padang. https://doi.org/10.31227/osf.io/kpc64

Heykal, M. (n.d.). Analisis Tingkat Pemahaman Kpr Syariah Pada Bank Syariah Di Indonesia: Studi Pendahuluan. Analisis Tingkat Pemahaman (9), 519-526.

Ikbal, M., \& Marlius, D. (2017). Pengaruh Jumlah Taksiran Dan Uang Pinjaman Terhadap Laba Bersih Pada PT. Pegadaian (UPC) Gurun Laweh. https://doi.org/10.31227/osf.io/uch4a

Imamah, N. (2012). Analisis Camel Untuk Mengukur Tingkat Kesehatan Bank PT. BPR Syariah Al-Mabrur Kabupaten Ponorogo Periode 2004-2008. Profit, 6(2012, June), 70-84.

Kasmir. (2013). Ruang Lingkup Lembaga Keuangan Bank. In Bank dan Lembaga Keuangan Lainnya (p. 36).

Laporan tahun 2015 PT. Bank Tabungan Negara (persero), Tbk. Kantor Cabang Padang.

Nugroho, S., \& Wahyuningrum, S. H. (2013). Kesesuaian Rumah Minimalis Terhadap Iklim Tropis. Modul, 13(1), 17-22.

Nur, S., \& Utomo, C. (2013). Analisa Nilai Agunan Rumah Tinggal di Medokan Asri Utara XII Surabaya, 2(2), 67-71.

Permana, T. R. I. O., Tinggi, S., \& Ekonomi, I. (2016). Pelaksanaan Pemberian Kredit Pemilikan.

Shanjaya, A. R., \& Marlius, D. (2017). Peranan Laporan Keuangan Dalam Kebijaksanaan Pemberian Kredit Kepada Calon Nasabah Pada PT. BPR Batang Kapas. https://doi.org/10.31227/osf.io/uxmg6

Sayekti, Nidya Waras Mauleny (2013).Kinerja Perbankan Syariah Di Indonesia

www.BTN.com 